\title{
Charcterization of Agronomic Traits and Grain Quality of Some Wheat Landraces
}

\author{
Amer, M. Abdel Aziz ${ }^{1}$ and Samaa M. Abd El-Rasool ${ }^{2}$
}

\begin{abstract}
This study was carried out at Nubaria Research Station Farm to evaluate of 12 wheat land races genotypes during two seasons 2014/15 and 2015/16. Analysis of variance was computed to measure genotypic and phenotypic coefficients of variation and broad sense heritability $\left(h^{2}\right)$ for yield and its components. Also, Chemical compositions of whole meal wheat genotypes were determined. Results indicated significant differences among wheat genotypes for all studied traits except spike length $(\mathrm{cm})$ in the combined data.

Results indicated that high values of genotypic (GCV) and phenotypic (PCV) coefficients of variation were obtained by grain yield $(67.84$ and 68.83$)$, followed by number of spike/m2 (35.54 and 38.57), number of kernel/ spike (34.02 and 36.33) and 1000-kernel weight (26.50 and 29.35) respectively. High heritability coupled with high genetic advance was observed for most traits. Whole meal wheat genotype $\mathrm{L} 1$ contain the highest content of crud protein and ash which were (13.23 and 2.01 \%) respectively. On the contrary, $\mathrm{L} 1$ had the lowest content $(82.78 \%)$ of carbohydrates. In addition to, the L10 had the highest crud fat content compared with the other wheat genotypes.
\end{abstract}

Key words: Wheat, Triticum aestivum, Variance coefficient, Heritability, Genetic gain.

\section{INTRODUCTION}

Bread wheat (Triticum aestivum L.) is one of the most widely grown crops in the world and Egypt, the local production is about 8 million tons, however it covers less than half of the local consumption. Increasing wheat productivity is a national target in Egypt to reduce the gap between wheat consumption and production. It is not possible to increase the area under production. Hence, only alternative is left to increase the productivity by introducing superior varieties and better management of crop production to cope up with increasing demands of food. A major cause of concern to a plant breeder is the constant improvement of the best available genotypes for further enhancement in their yield potential either directly or through improvement of various factors which contribute indirectly to high yield. Therefore, the only alternative strategic solution is to increase its productivity per feddan by applying the better crop management techniques and introducing high yielding cultivars characterized by tolerance against biotic and abiotic stresses.

Genetic diversity available in the existing germplasm determines the success of any crop improvement programme (Falconer and Mackay, 1996) and (Moose and Mumm, 2008). Therefore, quantitative assessment of genetic diversity present among population usually helps a plant breeder in choosing desirable parents for breeding programme. In whole grain wheat flour (WGWF) all the anatomical components of the grain, such as endosperm, bran and germ are present in the same proportions that exist in the intact form. Thus, WGWF contains substantially more fibers, vitamins, minerals and phytochemicals than refined wheat flour (RF). Accordingly, it is considered as an excellent source of nutritional and functional ingredients for human health with many associated benefits, including the reduction of diseases risk such as diabetes, cardiovascular diseases, obesity, and cancer (Liu, 2007).

The objective of the present study was to evaluate a set of 10 landraces and two chieks wheat with an aim, to analysis the genetic variability, heritability, and genetic advance for yield and its component traits. Furthermore, assess various biochemical grains under Nubaria conditions.

\section{MATERIALS AND METHODS}

\section{Plant materials and experimental design}

The present work was carried out at the Nubaria Research Station Farm during the two successive seasons of 2014/2015 and 2015/2016 to evaluate the yield performance of ten wheat landraces and two released Egyptian cultivars (Gemmeiza 9 and Giza 168). The detailed description of the code and pedigree of the tested genotypes are presented in Table (1).In each season, the plant materials were laid out in a randomized complete block design, with three replicates. Each plot consisted of six rows $3.5 \mathrm{~m}$ long and $20 \mathrm{~cm}$ apart. The total grain yield $(\mathrm{kg} / \mathrm{m} 2)$ was measured by harvesting each plot at crop maturity. Five plants were randomly chosen from each plot to measure the other yields components traits. Sowing dates were

\footnotetext{
${ }^{1}$ Genetic Resources Research Dept., Field Crops Research Institute, ARC, Giza, Egypt.

${ }^{2}$ Field Crop Research Department, Food Technology Research Institute ARC, Giza, Egypt.

Received March 05, 2018, Accepted March 31, 2018
} 
Table1.Code of ten landraces of number and pedigree of two check cultivars

\begin{tabular}{|c|c|c|c|c|c|c|c|c|}
\hline No & \multicolumn{3}{|c|}{ Genotypes } & \multicolumn{5}{|c|}{ Code number and /or origin } \\
\hline 1 & \multicolumn{3}{|c|}{ L1 } & \multicolumn{5}{|c|}{ G.S. N.3276 } \\
\hline 2 & \multicolumn{3}{|c|}{ L2 } & \multicolumn{5}{|c|}{ G.S. N.3359 } \\
\hline 3 & \multicolumn{3}{|c|}{ L3 } & \multicolumn{5}{|c|}{ G.S. N.3314 } \\
\hline 4 & \multicolumn{3}{|c|}{ L4 } & \multicolumn{5}{|c|}{ Assut 2799/38 } \\
\hline 5 & \multicolumn{3}{|c|}{ L5 } & \multicolumn{5}{|c|}{ Assut 2816/40 } \\
\hline 6 & \multicolumn{3}{|c|}{ L6 } & \multicolumn{5}{|c|}{ Assut 74} \\
\hline 7 & \multicolumn{3}{|c|}{ L7 } & \multicolumn{5}{|c|}{ Assut 3737} \\
\hline 8 & \multicolumn{3}{|c|}{ L8 } & \multicolumn{5}{|c|}{ Assut 3745} \\
\hline 9 & \multicolumn{3}{|c|}{ L9 } & \multicolumn{5}{|c|}{ G.S. N.3841 } \\
\hline 10 & \multicolumn{3}{|c|}{ L 10} & \multicolumn{5}{|c|}{ G.S. N.3845 } \\
\hline 11 & \multicolumn{3}{|c|}{ Gemmeiza 9} & & & & & \\
\hline 12 & \multicolumn{3}{|c|}{ Giza 168} & & & & & \\
\hline \multicolumn{9}{|c|}{$\begin{array}{l}\text { G. S. N. : Genetic Screening Nursery } \\
\text { Table 2.Mechanical and chemical characteristics of the soil at the experimental sites during } 2014 / 15 \text { and } \\
2015 / 16\end{array}$} \\
\hline \multirow{2}{*}{$\begin{array}{c}\text { Soil depth } \\
(\mathrm{cm})\end{array}$} & \multicolumn{4}{|c|}{ Particle size analysis \% } & & \multirow{2}{*}{$\mathrm{CaCO}_{3}(\%)$} & \multirow[b]{2}{*}{ pH } & \multirow{2}{*}{$\begin{array}{c}\text { E.C. } \\
\text { (ds/m) }\end{array}$} \\
\hline & Coarse sand & Fine sand & Silt & Clay & Texture class & & & \\
\hline $0-30$ & 11.4 & 35.7 & 26.4 & 26.5 & $\begin{array}{c}\text { Sandy clay } \\
\text { loam }\end{array}$ & 29.8 & 8.5 & 1.05 \\
\hline $30-60$ & 8.0 & 38.9 & 27.3 & 27.8 & $\begin{array}{c}\text { Sandy clay } \\
\text { loam }\end{array}$ & 30.1 & 8.3 & 0.90 \\
\hline
\end{tabular}

18 and 20 November in the two successive seasons, respectively.

The experiment was subjected to the recommended package of agronomic and protection practices at the proper time to obtain a healthy crop.

All the cultural practices were performed as recommended. The soil of the experimental site was calcareous and its physical and chemical properties were determined according to Page (1982) and presented in Table 2.

\section{Data collection:}

During the two seasons the following data were recorded

\section{Mean performance:}

Plant height $(\mathrm{cm})$, data of number of days to $50 \%$ heading (DH) and number of days to $50 \%$ maturity (DM) were recorded on plot basis, number of spikes $/ \mathrm{m}^{2}$, 1000-kernel weight (g), number of kernels/spike, spike length $(\mathrm{cm})$, and grain yield $(\mathrm{GY})$ was determined from the whole area of the plot $\left(10.5 \mathrm{~m}^{2}\right)$, then converted to the unit of (ardab/fad)

\section{Chemical analysis of samples:}

Moisture, crude protein ( $\mathrm{N} x$ 5.95), crude fat and ash content of samples were determined according to the method described in. Total carbohydrates were calculated by differences.

\section{Statistical analysis:}

Data were subjected to individual and combined analysis of variance (ANOVA) of randomized complete block design for each seasons and across them (Steel et al., 1997). Levene test (1960) was run prior to the combined analysis to test the homogeneity of individual error terms. Least significant difference (LSD) test was used to detect the significant differences among genotype means. The genotypic and phenotypic variances and their corresponding coefficients of variations were estimated, using the pertinent mean square expectations, according to the method, suggested by Johnson et al. (1955). Broad sense heritability $\left(\mathrm{h}^{2}\right)$ was estimated as described by Allard (1999).

Genetic parameters: Heritability in broad sense $\left(h^{2}\right)$ was determined as:

$$
\sigma^{2} g / \sigma^{2} p
$$

$\mathrm{EGA}=\mathrm{KH}^{2} \sigma$ phenotypic,

$$
E G A \%=\frac{E G A}{-} \times 100
$$

The predicted genetic advance under selection (EGA) was computed.

Where: $\mathrm{K}$ is the selection differential and equals to 2.06 upon selection the highest $5 \%$ of the population, $\mathrm{h}^{2}$ 
$=$ heritability is narrow sense and $\sigma \mathrm{Ph}=$ phenotypic standard deviation.

Phenotypic Coeficient of Variability $(\mathrm{PCV})=$

\begin{tabular}{cc} 
Phenotypic & Variance \\
\hline$\chi$
\end{tabular}

Phenotypic Coeficient of Variability $(\mathrm{PCV})=$

$\frac{\text { Genotypic Variance }\left(\sigma^{2} p\right)}{-}$

where, $\overline{\mathrm{x}}=$ grand mean of all entries. The PCV and GCV coefficients of variation were calculated according to Toker (1998). Genetic advance was calculated according to Allard (1960). Expected genetic advance (EGA) as percentage of the grand mean (EGA \%).

\section{RESULTS AND DISCUSSION}

\section{Field evaluation:}

Table (3) shows the mean values of wheat genotypes for agronomic characters. For heading date the earliest genotype was L5 (76.67), while L1 was the latest genotype (83.83). Meanwhile the tallest genotype was Gemmeiza 9 (105) on the other hand; L10 was the shortest genotype (75.5).

For the number of kernels/spike Giza 168 had the highest value (53.12) but L1 gave the lowest value (30.03). There is no significant difference among test genotypes for spike length. With respect to number of spikes $/ \mathrm{m}^{2}$ L5 had the highest number of spikes $/ \mathrm{m}^{2}$ (569.50), while L1 had the lowest number of spikes $/ \mathrm{m}^{2}$ (346.33). The highest spike length $(\mathrm{cm})$ gave 12.75 (cm) for each L1 and L6, while Giza 168 gave the least value $10.50(\mathrm{~cm})$. For 1000-kernel weight $(\mathrm{g})$ Gem.9 gave the highest value (48.14), while L1 gave the

Table 3. Mean performance of ten wheat landraces and two ckeck cultivars for agronomic characters (combined data)

\begin{tabular}{cccccccc}
\hline Genotype & $\begin{array}{c}\text { Number of days } \\
\text { to heading }\end{array}$ & $\begin{array}{c}\text { Plant height } \\
(\mathbf{c m})\end{array}$ & $\begin{array}{c}\text { Number of } \\
\text { kernels/spike }\end{array}$ & $\begin{array}{c}\text { Number of } \\
\text { spikes/m }\end{array}$ & $\begin{array}{c}\text { Spike length } \\
(\mathbf{c m})\end{array}$ & $\begin{array}{c}\text { 1000 Kernel } \\
\text { weight }(\mathbf{g})\end{array}$ & $\begin{array}{c}\text { Grain yield } \\
(\mathbf{a r d a b} / \mathbf{f a d})\end{array}$ \\
\hline L1 & 83.83 & 82.83 & 30.03 & 346.33 & 12.5 & 34.55 & 8.78 \\
L2 & 81.00 & 77.33 & 45.89 & 463.33 & 12.75 & 43.25 & 9.56 \\
L3 & 80.50 & 79.03 & 45.45 & 455.67 & 11.75 & 39.24 & 9.43 \\
L4 & 76.83 & 82.33 & 38.57 & 487.67 & 12.25 & 34.64 & 6.31 \\
L5 & 76.67 & 84.42 & 35.30 & 569.50 & 11.92 & 41.70 & 14.59 \\
L6 & 81.17 & 80.08 & 40.02 & 548.00 & 12.75 & 47.03 & 12.30 \\
L7 & 79.33 & 76.17 & 35.98 & 406.67 & 11.67 & 35.33 & 12.20 \\
L8 & 80.67 & 76.16 & 41.02 & 413.00 & 11.33 & 44.93 & 10.85 \\
L9 & 82.17 & 76.58 & 39.69 & 384.33 & 11.25 & 37.04 & 8.11 \\
L10 & 78.67 & 75.50 & 41.02 & 447.83 & 11.92 & 43.23 & 15.73 \\
Gem. 9 & 82.00 & 105 & 48.80 & 541.00 & 11.08 & 48.14 & 19.08 \\
Giza 168 & 79.00 & 95 & 53.12 & 455.50 & 10.50 & 36.08 & 17.41 \\
LSD at & 2.55 & 5.198 & 7.10 & 78.67 & N.S & 6.129 & 3.185 \\
(0.05) & & & & & &
\end{tabular}

lowest value (34.55). With respect to grain yield (ardab/fed). Gem. 9 had the greatest value grain yield (19.08). On the other hand, L9 had the lowest grain yield (8.11).

\section{Genetic parameters}

Table 4. Presents the genetic parameters studied. The phenotypic coefficient of variation (PCV) was greater than genotypic coefficient of variation (GCV) for all the studied characters indicating role of environmental interaction in the expression of the characters. These results were in agreement with (Gollen et al. 2011). A perusal coefficients of variation revealed that the highest GCV and PCV were observed for grain yield $(67.84 \%, 68.83 \%)$ followed by , number of spikes $/ \mathrm{m}^{2}(34.02-36.33)$, number of kernels per spike (34.02\%, 36.33\%), and 1000-grain weight (26.5-29.35). Similar results were harmony with (Kaul and Singh,

Table (4) shows that high values of heritability were found for grain yield followed by, days to heading, number of kernels/spike, and number spikes $/ \mathrm{m}^{2}$. This shows the presence of additive gene effect and selection may be made for the improvement of these traits. Although low heritability exhibited that the characters were highly influenced by environmental effect and genetic improvement through selection will be difficult due to effect of environment (Arya et al., 2017).

The expected genetic advance (EGA \%) ranged from 12.75 to $67.47 \%$. The highest EGA was observed for spike lenght and grain yield. High heritability coupled with high genetic advance as percent mean were revealed for number of spikes $/ \mathrm{m}^{2}$, 1000- kernel weight, number of kernels/spike and grain yield. 2011 and Kumar et al. 2013). 
Table 4.Genetic parameters of grain yield and its related characters computed from ten landraces and tow check cultivars across both seasons combind

\begin{tabular}{lllllll}
\hline & \multicolumn{9}{c}{ Genetic parameters } \\
\cline { 2 - 7 } Characters & $\begin{array}{l}\text { Grand } \\
\text { mean }\end{array}$ & G CV & Ph CV & $\mathbf{H}^{\mathbf{2}}$ & \multicolumn{2}{c}{ Genetic advance } \\
\hline Days to heading & 80.153 & 6.45 & 6.72 & 92.09 & 10.22 & 12.75 \\
Plant height (cm) & 78.68 & 10.27 & 12.39 & 68.68 & 13.78 & 17.52 \\
Number of kernels/spike & 40.52 & 34.02 & 36.33 & 87.71 & 10.30 & 25.42 \\
Number of spikes/m & 459.90 & 35.54 & 38.57 & 84.90 & 310.30 & 67.47 \\
Spike length (cm) & 11.81 & 12.97 & 14.35 & 81.67 & 2.84 & 24.12 \\
1000-Kernel weight (g) & 43.43 & 26.50 & 29.35 & 81.52 & 13.24 & 30.49 \\
Grain yield (ardab/fad ) & 15.148 & 67.84 & 68.83 & 97.00 & 20.84 & 37.58 \\
\hline
\end{tabular}

Similar results were reported by Nagireddy and Jyothula, (2009) and Khokhar et al., (2010). This indicates substantial contribution of additive gene action in the expression of the characters (Kuobaili and Khoury 2005).

Chemical composition of whole meal wheat genotypes (g/100g on dry weight basis)

The chemical composition of whole meal wheat genotypes was determined and the results are recorded in Table (5). The moisture content of whole meal wheat genotypes ranged from (11.26 to $12.71 \%$ ).

However, whole meal wheat genotype L1 contains the highest content of crud protein which was (13.23\%) followed by whole meal wheat genotype L9 which recorded $(12.85 \%)$ while the lowest value of crud protein was $(10.96 \%)$ for whole meal wheat genotype
L8. These results are in line with those Nemat, et al. ( 2011) . They reported that, crude protein of wheat seeds were ranged from 10.2 to $12.6 \%$ depending on genotypes .

Apparent also from the same table that, whole meal wheat genotypes contain $(1.58$ to $2.18 \%)$ crud fat, In addition to; the L10 gave the highest crud fat content compared with the other wheat genotypes.

The highest content of ash was recorded for the genotype L1 $(2.01 \%)$ followed by L10 $(1.99 \%)$ while, the Giza 168 had the lowest value; $1.67 \%$. These results were in the same trend with those reported by (Protonotariou, et al., 2016 and Bressiani, et al., 2017).

Results also revealed that the highest carbohydrates content was found in L8 $(85.55 \%)$ compared with L1 which had the lowest content $(82.78 \%)$.

Table 5. Proximate chemical composition (\%)of whole meal wheat genotypes (on dry weight basis)

\begin{tabular}{lccccc}
\hline Genotypes & Moisture\% & crude Protein \% & crude Fat\% & Ash\% & $\begin{array}{c}\text { Total } \\
\text { carbohydrates } \%\end{array}$ \\
\hline L1 & $11.26 \mathrm{~b}$ & $13.23 \mathrm{a}$ & $1.98 \mathrm{a}$ & $2.01 \mathrm{a}$ & $82.78 \mathrm{e}$ \\
L2 & $12.25 \mathrm{ab}$ & $11.91 \mathrm{~b}$ & $1.87 \mathrm{ab}$ & $1.72 \mathrm{~b}$ & $84.50 \mathrm{~b}$ \\
L3 & $11.28 \mathrm{~b}$ & $11.69 \mathrm{bc}$ & $1.82 \mathrm{ab}$ & $1.85 \mathrm{ab}$ & $84.64 \mathrm{~b}$ \\
L4 & $12.51 \mathrm{a}$ & $11.23 \mathrm{c}$ & $1.58 \mathrm{~b}$ & $1.83 \mathrm{ab}$ & $85.36 \mathrm{a}$ \\
L5 & $12.60 \mathrm{a}$ & $12.65 \mathrm{ab}$ & $2.01 \mathrm{a}$ & $1.75 \mathrm{~b}$ & $83.59 \mathrm{~d}$ \\
L6 & $12.21 \mathrm{ab}$ & $11.51 \mathrm{c}$ & $1.81 \mathrm{ab}$ & $1.85 \mathrm{ab}$ & $84.83 \mathrm{~b}$ \\
L7 & $11.36 \mathrm{~b}$ & $12.81 \mathrm{ab}$ & $2.06 \mathrm{a}$ & $1.73 \mathrm{~b}$ & $83.40 \mathrm{~d}$ \\
L8 & $12.02 \mathrm{ab}$ & $10.96 \mathrm{c}$ & $1.67 \mathrm{~b}$ & $1.82 \mathrm{ab}$ & $85.55 \mathrm{a}$ \\
L9 & $11.28 \mathrm{~b}$ & $12.85 \mathrm{ab}$ & $2.07 \mathrm{a}$ & $1.75 \mathrm{~b}$ & $83.33 \mathrm{~d}$ \\
L10 & $12.71 \mathrm{a}$ & $11.83 \mathrm{bc}$ & $2.18 \mathrm{a}$ & $1.99 \mathrm{a}$ & $84.00 \mathrm{c}$ \\
Gem. 9 & $11.65 \mathrm{~b}$ & $12.01 \mathrm{~b}$ & $2.15 \mathrm{a}$ & $1.89 \mathrm{ab}$ & $83.95 \mathrm{c}$ \\
Giza 168 & $11.48 \mathrm{~b}$ & $12.40 \mathrm{~b}$ & $1.86 \mathrm{ab}$ & $1.67 \mathrm{~b}$ & $84.07 \mathrm{c}$
\end{tabular}

* Each value is an average of three determinations.

+ Values followed by the same letter in Colum are not significantly different at $\mathrm{P} \leq 0.05$

**Total carbohydrates was calculated by difference. 


\section{REFERENCES}

Allard, R. W. 1999. Principals of Plant Breeding. $2^{\text {nd }}$ ed. John Wiley \& Sons, New York.USA.

Allard, R.W. 1960. Principles of Plant Breeding. $1^{\text {st }}$ Edn., John Wiley and Sons Inc., New York.

Arya, V. K., J. Singh, L. Kumar, R. Kumar, P. Kumar and P. Chand .2017. Genetic variability and diversity analysis for yield and its components in wheat (Triticum aestivum L.). Indian J. Agric. Res. 51(2):128-134.

Bressiani, J., T. Oro, G. Santetti, j. Almeida, T. Bertolin, M. omez and L. Gutkoski.2017. Properties of whole grain wheat flour and performance in bakery products as a function of particle size .J. of Cereal Science,75: 269- 277.

Falconer, D. S. and T. F. C. Mackay.1996. Introduction to Quantitative Genetics (4th ed.). Longman Essex, UK.

Gollen, B., R. K. Yadav, and P. Kumar.2011. Assessment of genetic parameters for spike traits and yield attributes in bread wheat genotypes following Line $\mathrm{X}$ Tester mating system. Environment and Ecology. 29(2):752-756.

Johnson, H. W., H. F. Robinson and R. E. Comstock.1955. Estimation of genetic and environmental variability in soybean. Agron. J. 47:314-318.

Kaul, D.K. and B. Singh .2011.Evolution for drought Tolerance in elite genotypes of Bread Wheat (Triticum aestivum L.). Advances in Plant Sciences 24 (1): 141-144.

Khokhar, M. I., M. Hussain, M. Zulkiffal, W. Sabir, S. Mahmood and M. W. J. Anwar .2010. Studies on genetic variability and inter-relationship among the different traits in wheat (Triticum aestivum L.) Krmiva. 52(2): 77-84.

Kumar, R., S. S. Gaurav, B. Bhushan and R. Pal.2013. Study of genetic parameters and genetic divergence for yield and yield components of bread wheat (Triticum aestivum L.). J. Wheat Res. 5(2): 39-42.
Kuobaili, S. and B. Khoury.2005. Yield components and harvest index in durum wheat under syrian coastal conditions. Tishreen University Journal for Studies and Scientific Research- Biological Sciences.27(1): 60-71.

Levene, H. 1960. Robust tests for equality of variances. In ingram Olkin, Harold Hotel Ling, Italia Stanford, Univ. Press.PP. 278- 292.

Liu, R. H. 2007. Whole grain phytochemicals and health. J. Cereal Sci.46: 207-219.

Moose, S. P. and H. M. Rita .2008. Molecular plant breeding as the foundation for $21^{\text {st }}$ centuary crop improvement. Plant Physiol. 147: 969-977.

Nagireddy, A. V. and D. P. B. Jyothula .2009. Heritability and interrelationship of yield and certain agronomic traits in wheat. Research on Crops. 10(1): 124-127.

Naguib, N. A., E. A. Mohamed and N.A. El-Aidy .2011. Effect of storage period and packaging material on wheat (Triticum aestivum L.) viability and quality. Egypt J. Agric. Res. 89(4):1481-1497.

Page, A. L. 1982. Methods of soil analysis. 2nd Edn., Amercen Society of Agronomy, Madison, WI., USA.

Protonotariou, S., C. Batzaki and S. Y. Mandala. 2016. Effect of jet milled whole wheat flour in biscuits properties Food Science and Technology. 74: 106-113.

Steel. R. G. D., J. H. Torrie and D. A. Dickey .1997. Principles and Procedures of Statistics: A Biometrical Approach. $3^{\text {rd }}$ ed. Mc Graw Hill Book Co. New York.U.S.A.

Toker, C.1998. Estimate of heritability and genotype by environment interaction for 100 -seed weight, days to flowering and plant height in Kabuli chickpeas (Cicer arietinum L). Turk. J. Field Crops.3: 16-20. 


\section{الملخص العربي}

\section{توصيف بعض صفات المحصول والجودة لبعض سلالات القمح}

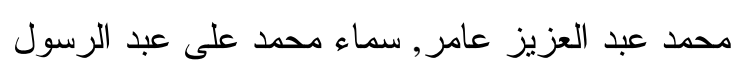

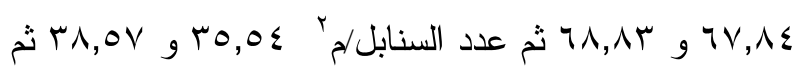

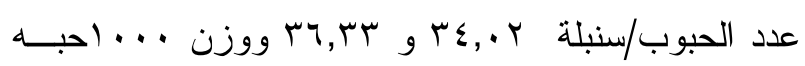
•

ولوحظ ارثفاع درجة التوريث الى جانب التقدم الوراثى

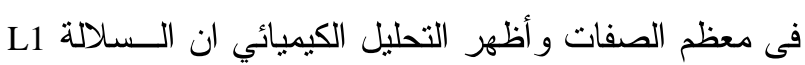

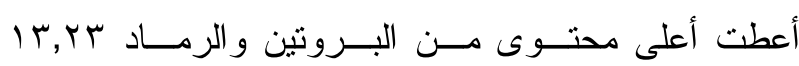

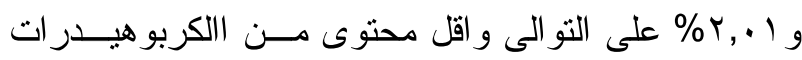
\%^r,vA محتوى من الدهن مقارنة بالتر اكيب الوراثية الأخرى مسن

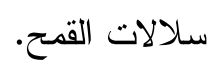

أجريث هذه الدراسة فى المزرعة البحثية بمحطة بحوث بالنوباريه لتقييم ب إن تركيب وراثى خلال الموسمين

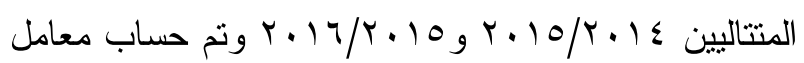
الإختلاف الوراثى والمظهرى ودرجة التوريث بالمعنى

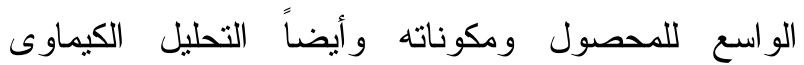
للحبوب.أوضحت النتائج وجود فروق معنوية بين كل الصفات المدروسة فى كل التر اكيب الوراثية ماعدا صفة طول السنبلة.

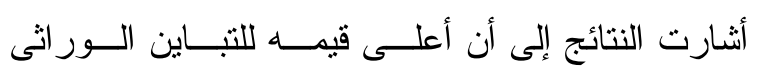

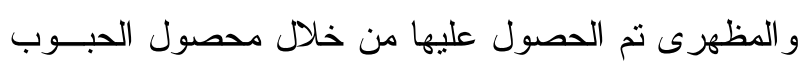

